\title{
CONE PENETRATION TEST AND PILE RECOMENDATION IN THE RICE FIELD: A CASE STUDY AT BOGOR AGRICULTURAL UNIVERSITY OUTSIDE DOMICILE STUDY PROGRAM DEVELOPMENT AREA OF SUKABUMI, WEST JAVA
}

\author{
Pratama Gilang Ardi \\ Industrial Engineering Department, University of Pamulang, Indonesia \\ E-mail: dosen01860@unpam.ac.id \\ ORCID: 0000-0003-1621-1358
}

\begin{abstract}
This study was conducted on cone penetration test data existed in the plan area of the Bogor Agricultural University's outside domicile study program. The purpose of this study is to calculate the bearing capacity of piles resulted from cone penetration and material strength, compare the bearing capacity of piles to be recommended. The data collection methodology was done by observation and retrieving data in the field. The layer with conical resistance value (qc)> $250 \mathrm{~kg} / \mathrm{cm}^{2}$ was found in the depth of $7.2 \mathrm{~m}$ from existing ground elevation for $\mathrm{s} 1$. For s2, it could be found at the depth of $7.6 \mathrm{~m}$ from existing ground elevation, while for $\mathrm{s} 3$, it was at the depth of $4.8 \mathrm{~m}$ from ground elevation.
\end{abstract}

\section{KEY WORDS}

Cone penetration test, engineering management, study program, rural development.

In any construction, the first thing to do is the foundation work (bottom structure) and then carries out the upper structure work. To build a foundation is very important on a construction. In general, the foundation is defined as an underground building which forwards the building's internal load and the external load working on the building to the surrounding ground.

The bottom structure of a foundation is also generally divided into two types: shallow foundation and deep foundation. The selection of both depends on the type of upper structure, whether it is light or heavy load construction, as well as the type of soil. For light load construction and good soil surface conditions, the shallow foundation type is adequate. But for heavy load construction, the deep foundation type is an option, and generally, its foundation planning problems are more complicated than the shallow one (sihotang, 2009).

The CPT methods used in this paper were developed based on data obtained from the friction cone with total cone tip resistance. (qc) measurement. During the past two decades many investigators (Tumay et al. 1982; Campanella and Robertson 1988) have demonstrated the need for correcting the cone tip resistance for the pore pressure generated behind the cone base, especially in soft cohesive soils. Also the CPT can used to provide additional information on pore water pressure measurements (De Ruiter, 1982). Main advantages of using CPT data for geotechnical purposes are, continuous or near continuous readings with depth, repeatable and reliable penetration data, and cost effectiveness (jakasa, 2000).

Recently Institut Pertanian Bogor (Bogor Agricultural University) inaugurated an Outside Domicile Study Program or Multi-Campus Education located in Sukabumi. It aims to improve the rural communities' accessibility to get a decent education. IPB's PDD is planned to expand about another 20 hectares dedicated to the afrobusiness development zone located in Sukabumi.

Therefore it is necessary to investigate and obtain information in the form of required soil data, both for planning and for implementation. The soil data will facilitate the substructure planning and analyze (the bottom of the building). In addition, the data obtained can be at least comparable, particularly to similar soil investigations and provide appropriate stakeholder recommendations for development in IPB's PDD campus area in order to improve agricultural education for rural communities. 


\section{LITERATURE REVIEW}

The soil in nature according to Soil Survey Staff (1975), Soil is the collection of natural bodies on the earth's surface, in places modified or even made by man of earthy materials, containing living matter and supporting or capable of supporting plants out-of-doors. Its upper limit is air or shallow water. At its margins it grades to deep water or to barren areas of rock or ice. Its lower limit to the not-soil beneath is perhaps the most difficult to define. Soil includes the horizons near the surface that differ from the underlying rock material as a result of interactions, through time, of climate, living organisms, parent materials, and relief. In the few places where it contains thin cemented horizons that are impermeable to roots, soil is as deep as the deepest horizon. More commonly soil grades from at its lower margin to hard rock or to earthy materials virtually devoid of roots, animals, or marks of other biological activity. The lower limit of soil, therefore, is normally the lower limit of biological activity, which generally coincides with the common rooting depth of native perennial plants. Yet in defining mapping units for detailed soil surveys, lower layers that influence the movement and content of water and air in the soil or the root zone must also be considered.CPT or cone penetration is a cylindrical tool with a conical end. In CPT test, the tool handlebar is pressed into the ground and then provides ground resistance against the tip of the CPT , then friction on the cylindrical blanket is measured.

According to Wibowo (2011), this method is then known by various names such as static penetration test or quasi-static penetration test, dutch cone test, and briefly called sounding which means estimation. In Indonesia, it then called sondir which is taken from the Dutch language. The current CPT is one of the field tests which have been accepted by practitioners and geotechnical experts. The CPT test has demonstrated a benefit for predicting profile or coating soil against the depth as the soil behavioral type has been identified from the combination of end-resistance and friction blankets readings. An important scale measured in the CPT is the end-resistance taken as the width unified penetration force of the CPT tip (qc). The value of this force often indicates the identification of soil type and its consistency. On the sandstone soil, the end-resistance is greater than the fine grain.

The conical resistance value of CPT results in the soil/rock layer can be linked empirically with its strength. In fine-grained soil (clay-silt), the relative hardness level can be determined. While on coarse-grained soil (sand-gravel), the level of relative density can be determined based on the consistency of clay soil based on table 1 from (Terzaghi and Peck, 1996):

Table 1 - The consistency of Clay Soil Based on Result of CPT

\begin{tabular}{|c|c|c|}
\hline The consistency & Conus resistance $(\mathrm{Qc})\left(\mathrm{kg} / \mathrm{cm}^{2}\right)$ & Friction ratio (\%) \\
\hline Very soft & $<5$ & 3.5 \\
\hline Soft & $5-10$ & 3.5 \\
\hline Firm & $10-35$ & 4 \\
\hline Stiff & 30 & 4 \\
\hline Very Stiff & $60-120$ & 6 \\
\hline Hard & $>120$ & 6 \\
\hline
\end{tabular}

During classification of soils according to Robertson (1986 or 2010) it is not necessary to input parameters of soils; the program performs this step automatically with their assignment to the geological profile. For this reason, the assessment of the performed CPT is very fast and especially clear. Classification of soils according to Robertson (1986 or 2010) is based on the measured values of penetration resistance qc, local skin friction fs, pore pressure $\mathrm{u} 2$ respectively. Based on the corrected value of the cone resistance $q \mathrm{t}=\mathrm{qc}+\mathrm{u} 2$ * $(1-a)$, or percentage ratio $\mathrm{qc} / \mathrm{pa}$ and friction ratio $\mathrm{Rf}=\mathrm{fs} / \mathrm{qt}$ program automatically performs the assignment of soil behavior type (SBT) according to the following graphs. pa atmospheric pressure $=100 \mathrm{kPa}(=1 \mathrm{tsf})$. 


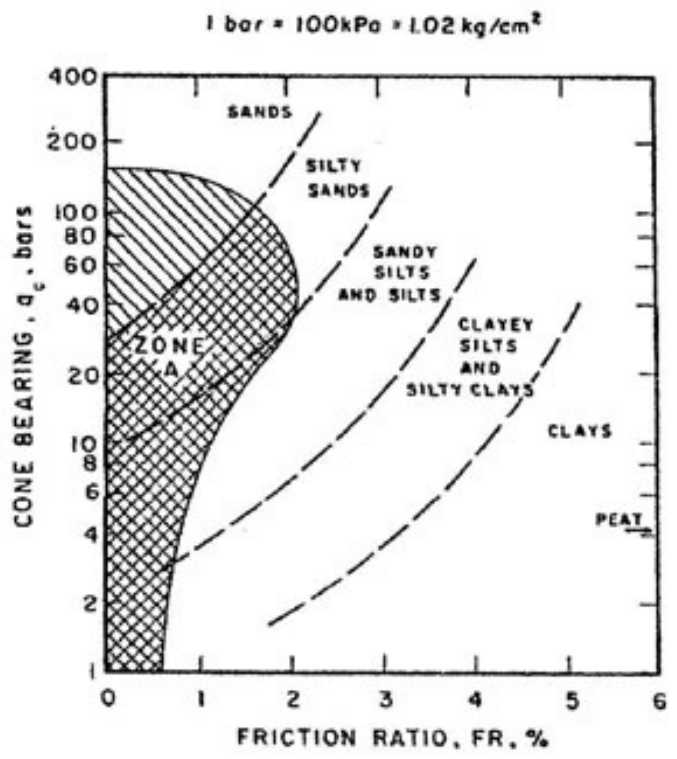

Figure 1 - Classification of soils (Robertson, 2010)

The conical resistance value of CPT results in the soil/rock layer can be linked empirically with its strength. In fine-grained soil (clay-silt), the relative hardness level can be determined. While on coarse-grained soil (sand-gravel), the level of relative density can be determined based on the consistency of clay soil based on table 1 :

$$
Q u=q_{c} x A_{p}+J H L x K_{t}
$$

Where:

Qultimate $=$ the bearing capacity of the pile;

$\mathrm{QC}_{\mathrm{C}}$ the end-resistance of the CPT;

$A=$ the sectional area of the pile;

$\mathrm{JHL}=$ number of obstacles sticking along the conical skin;

$\mathrm{Kt}=$ the circumference of the pile.

After determining the bearing capacity of soil boundaries, next is finding the allowable bearing capacity out. This is intended to prevent the load exceeds soil's retaining limit.

The calculation uses the Meyerhoff formula:

$$
\mathrm{Q}_{\mathrm{ult}}=\frac{q_{p} \cdot A_{p}}{3}+\frac{J H L * k l l}{5}
$$

Where:

$\mathrm{Pa}=$ the bearing capacity of the pile press (TON);

$\mathrm{Qp}=$ the result of CPT conus value $\left(\mathrm{kg} / \mathrm{cm}^{2}\right)$;

$\mathrm{Ap}=$ the sectional area of the pile $(\mathrm{kg} / \mathrm{cm})$;

$\mathrm{KII}=$ the circumference of the pile blanket $(\mathrm{cm})$;

$\mathrm{JHL}=$ the number of obstacles sticking along the conical skin;

FK1 and FK 2 = the security factors, which are 3 and 5 respectively.

However, the calculation of allowable bearing capacity can be calculated by using the material strength. It is intended to prevent the load exceeds material's retaining limit.

Where:

$$
P_{\text {Pile }}=\frac{\sigma_{b} \cdot A_{\text {oile }}}{S F}
$$

$\mathrm{P}_{\text {Pile }}=$ the bearing capacity of pile press $(\mathrm{TON})$;

$A p=$ the sectional area of pile $(\mathrm{kg} / \mathrm{cm})$;

$\mathrm{SF}=$ Security Factor $3-5$. 


\section{METHODS OF RESEARCH}

The step to simply determine the exact condition of research location's subsurface was collecting the soil hardness data by conducting the CPT test with a light load CPT device. With the capacity of jacket 2,5 tons, it was attributed with cone jacket adhesion which can measure the value of conical resistance and attached obstacles. The number of data retrieval points was three points with the capacity of 2.5 tons.

The data collection was carried out in the campus area of Program outside Domicile (POD) Bogor Agricultural University precisely in Limusnunggal, Sukabumi, Sukabumi, West Java 43165.

This CPT work was conducted until it had reached hard soil layer, where the value of conus resistance was $>250 \mathrm{~kg} / \mathrm{cm}^{2}$ or had reached the sticking obstacle of 2.50 tons. The result of the foundation is presented in the form of CPT diagram showing the relationship between the depth of underground CPT and the value of conus resistance as well as the number of adhesive resistance (TF)

From the data of each point, the value of soil boundaries' bearing capacity and the soil permission bearing capacity were calculated. The result will be the basis to calculate for the recommended bearing capacity of the pile.

\section{RESULTS AND DISCUSSION}

Based on the data of soil investigation in the field, the basic soil condition in PDD IPB's campus development area can be explained in the picture below.

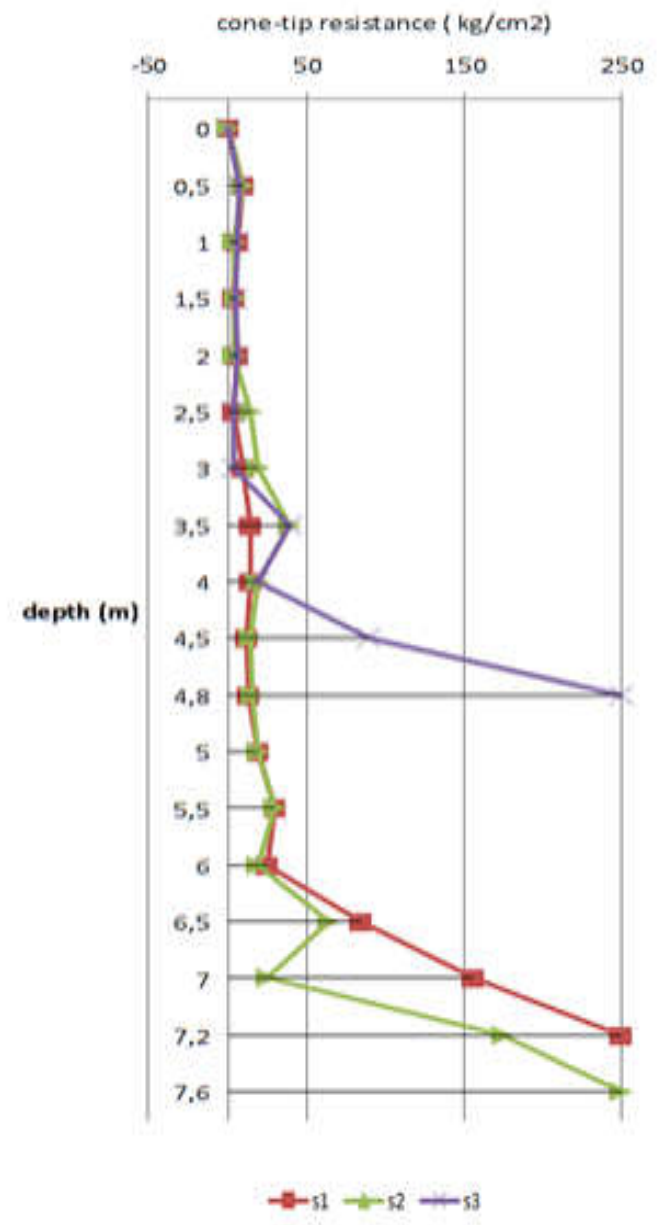

Figure 2 - The Chart of Conus Resistance to Depth

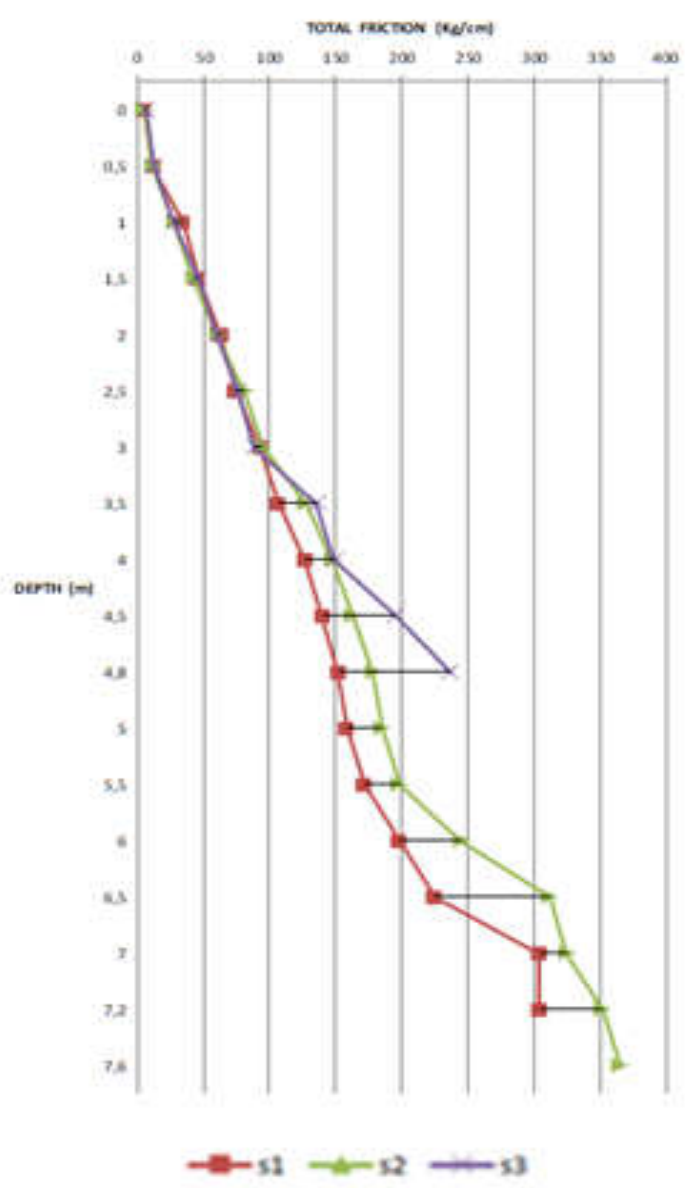

Figure 3 - The Chart of Total Friction to Depth 


\begin{tabular}{|c|c|c|}
\hline No & Depth & Soil Description \\
\hline 1 & $0-3 m$ & $\begin{array}{l}\text { Consisted of silty clay layer type with a soft to medium stiff consistency. The yellowish-brown } \\
\text { layer has a conical resistance of } 4-7 \mathrm{~kg} / \mathrm{cm} 2 \text { and a shear resistance of } 5-95 \mathrm{~kg} / \mathrm{cm} \text {. }\end{array}$ \\
\hline 2 & $3-6 m$ & $\begin{array}{l}\text { It is a type of clayey silt layer with a steady consistency level (medium stiff to stiff). The yellowish- } \\
\text { brown color layer has averaged CPT 's conical resistance value }(q c) \text { between } 10-20 \mathrm{~kg} / \mathrm{cm}^{2} \text { and } \\
\text { shear resistance of } 93-245 \mathrm{~kg} / \mathrm{cm} \text {, but the result of CPT s3 reaches maximum penetration at } \\
\text { depth } 4,8 \mathrm{~m} \text {. }\end{array}$ \\
\hline 3 & $6-7 m$ & $\begin{array}{l}\text { It is a silty clay to clayey silt layer with a very steady consistency level (very stiff to hard) where } \\
\text { the CPT 's conical resistance value obtained is approximately between } 30-150 \mathrm{~kg} / \mathrm{cm}^{2} \text { and shear } \\
\text { resistance of } 245-352 \mathrm{~kg} / \mathrm{cm} \text {. }\end{array}$ \\
\hline 3 & $>7 m$ & $\begin{array}{l}\text { It is a hard-layer soil where the CPT 's conical resistance value (qc) reaches the maximum tool } \\
\text { capacity of } 250 \mathrm{~kg} / \mathrm{cm}^{2} \text { and shear resistance of more than } 352 \mathrm{~kg} / \mathrm{cm} \text {. }\end{array}$ \\
\hline
\end{tabular}

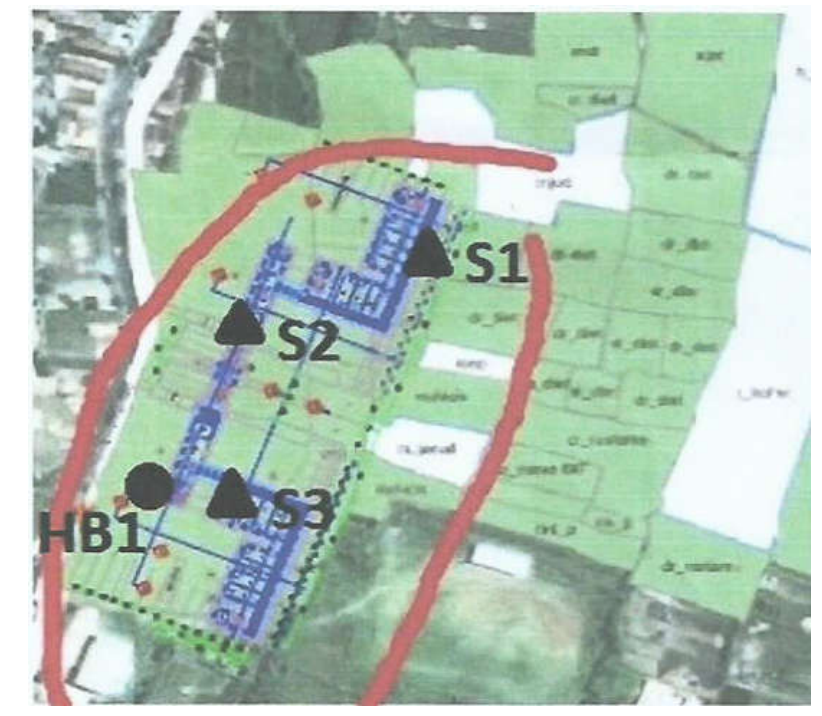

Figure 4 - Research Location

Therefore, for buildings with light loads, the use of shallow type foundation will be at risk of decline, but it can still be applied as long as the workload is still smaller when compared to the bearing capacity of the basic soil permission in the existing area. It can be assessed by gut sanglerat calculation:

$$
\begin{gathered}
\mathrm{q}_{\mathrm{a}}=\frac{q c}{S F} \mathrm{sf}-------->20 \\
\mathrm{q}_{\mathrm{a}}=\frac{q c}{20} \\
\mathrm{q}_{\mathrm{a}}=\frac{4}{20}=0,2 \mathrm{~kg} / \mathrm{cm}^{2}
\end{gathered}
$$

From the calculation above, it can be stated that the existing layer of soil with a depth of $1 \mathrm{~m}$ has the basic soil bearing capacity by $0.2 \mathrm{~kg} / \mathrm{cm} 2$

The analysis of pile foundation's bearing capacity in the opening area of IPB's Outside Domicile Study Program aimed to know the bearing capacity of the pile against the load. The recommendation of pile dimension would be divided into two, namely, mini pile with k450 and bore pile with $\mathrm{k} 250$ concrete.

The analysis performed in Table 2 show that the soil resistance can withstand the maximum load charged by the mini pile, making it less likely to degradation of the soil.

Table 2 - The recommendation of mini pile K-450 and conus resistance of $250 \mathrm{~kg} / \mathrm{cm}^{2}$

\begin{tabular}{|c|c|c|}
\hline Dimension (cm) & $\begin{array}{c}\text { The bearing capacity based } \\
\text { on the conus resistance (ton) }\end{array}$ & $\begin{array}{c}\text { The bearing capacity based } \\
\text { on material strength (ton) }\end{array}$ \\
\hline $20 \times 20$ & 36 & 36 \\
\hline $25 \times 25$ & 56 & 56 \\
\hline $28 \times 28 \times 28$ & 39 & 35 \\
\hline $32 \times 32 \times 32$ & 49 & 46 \\
\hline
\end{tabular}


Table 3 - The recommendation of bore pile K-225 and conus resistance of $250 \mathrm{~kg} / \mathrm{cm} 2$

\begin{tabular}{|ccc|}
\hline Diameter $(\mathrm{cm})$ & $\begin{array}{c}\text { The Bearing Capacity Based } \\
\text { on Conus Resistance (ton) }\end{array}$ & $\begin{array}{c}\text { The Bearing Capacity Based } \\
\text { on Material Strength (ton) }\end{array}$ \\
\hline 40 & 114 & 57 \\
\hline 50 & 175 & 88 \\
\hline 60 & 249 & 127 \\
\hline
\end{tabular}

The analysis performed in Table 2 shows that the ground resistance can withstand the maximum load charged by the bore pile so that it is less likely to degradation of the soil. The contractor can also add the quality of concrete to k-400 to increase the bearing capacity of material at the stake.

\section{CONCLUSION}

From the result of soil investigation above, it is noted that the layer with CPT conical resistance value (qc)> $250 \mathrm{~kg} / \mathrm{cm} 2$ was found in the depth of $7.2 \mathrm{~m}$ from the ground elevation for $\mathrm{s} 1$. For s2, it could be found at the depth of $7.6 \mathrm{~m}$ from the ground elevation, while for $\mathrm{s} 3$, it was at the depth of $4.8 \mathrm{~m}$ from the ground elevation. The ' $h$ ' existing, as well as the recommended mini pile and bore pile, are proposed to ensure that the material resistance does not exceed conus resistance to avoid a soil degradation.

\section{REFERENCES}

1. Campanella, R. G., and Robertson, P. K. 1988. "Current status of the piezocone test." Proc., 1st Int. Symp. on Penetration Testing, ISOPT-1, Orlando, Fla., Vol. 1, 93-116.

2. J.D. Ruiter, 1982, "The Static Cone Penetration Test, State of the Art Report", Proceedings of the 2nd European Symposium on Penetration Testing, 1982. P389-405,

3. M.B. Jakasa, W.S. Kaggwa and P.I. Brooker. 2000."An Improved Technique for Evaluating the CPT Friction Ratio", Department of Civil and Environmental Engineering University of Adelaide, Research Report No. R. 166, January 2000.

4. Meyerhof G.G., Bearing Capacity and Settlement of Pile Foundations, ASCE J. of Geotechnical Eng., 1976, GT3, 195-228.

5. Robertson, P. K., 1986. "Use of piezometer cone data." Proc., ASCE Specialty Conf. In Situ'86: Use of In Situ Tests in Geotechnical Engineering, New York, 1263-1280.

6. Robertson, P.K., 1990. Soil classification using the cone penetration test. Canadian Geotechnical Journal, 27(1): 151-158.

7. Robertson, P.K. (2010) Soil Behaviour Type from the CPT: An Update. 2nd International Symposium on Cone Penetration Testing, Huntington Beach, Vol. 2, 575-583.

8. Sihotang, Sulastri. 2009. Analisa Daya Dukung Pondasi Tiang Pancang Pada Proyek Pembangunan Gedung Kanwil DJP dan KPP Sumbagut 1 Jalan Suka Mulia Medan (Tugas Akhir). Jurusan Teknik Sipil, Universitas Sumatera Utara, Medan

9. Soil Survey Staff. 1975. Soil taxonomy: a basic system of soil classification for making and interpreting soil surveys. US Department of Agriculture, Soil Conservation Service. U.S. Government Printing Office, Washington, DC.

10. Terzaghi, Karl and Ralph B Peek.1996. Soil Mechanics in Engineering Practice 3rd edition, wiley-interscience publication, new york

11. Tumay, M. Y., 1982. "Subsurface investigation with piezocone penetrometer." Proc., Cone Penetration Testing and Experience, ASCE, New York, 325-342.

12. Tumay, M. T., 1982. "Friction pile capacity prediction in cohesive soils using electric quasi-static penetration tests." Interim Research Rep. No. 1, Louisiana Department of Transportation and Development, Research and Development Section, Baton Rouge, La.

13. Wibowo, H, T. 2011. Analisis Hasil Pengujian CPT Untuk Mengetahui Peningkatan Kekuatan Tanah Sangat Lunak di Lokasi Gate House Dalam Pekerjaan "Grouting At Semanrang Pumping Station \& Retarding Pond". Program Studi Teknik Geologi Universitas Diponegoro, Semarang. 